\title{
Az olvasástanítás eredményessége az iskola kezdő szakaszában a Covid19 időszaka alatt: a pedagógusok és a szülők megítélése
}

\author{
Józsa Krisztián ${ }^{1}$ és Pasztendorf Gabriella ${ }^{2}$ \\ ${ }^{1}$ Szegedi Tudományegyetem Neveléstudományi Intézet, \\ Magyar Agrár-és Élettudományi Egyetem Neveléstudományi Intézet \\ ${ }^{2}$ Kiskunhalasi Fazekas Mihály Általános Iskola, Kiskunhalas
}

\begin{abstract}
Absztrakt
A Covid19-vírus következtében kialakult járványhelyzet miatt 2020 márciusától Magyarországon is bezártak az iskolák. A Kormány digitális munkarendet vezetett be, a gyermekek otthon tanultak, amit a pedagógusok távolléti oktatás formájában segítettek. Kevés információ áll egyelőre még rendelkezésre arról, hogy az így bevezetett digitális oktatás milyen hatékonysággal bírt. Nem ismert, hogy az osztálytermi oktatáshoz képest milyen mértékben tér el a távolléti oktatás idején elsajátított tudás. A vizsgálat célja ezért az volt, hogy adatokat gyűjtsünk a kezdő olvasástanítás, -tanulás eredményességéről. Az első és második évfolyamon tanító pedagógusok, valamint a szülők tapasztalataira voltunk kíváncsiak a távolléti oktatás idején folyó olvasástanításról. Online kérdőívvel gyüjtöttünk adatokat, a válaszadás önkéntes és anonim volt. A kérdőíveket 117 pedagógus és 83 szülő töltötte ki. Eredményeink rámutattak, hogy a vírus alatti időszakban a pedagógusok elsősorban a tradicionális olvasástanítási módszereket igyekeztek adaptálni a digitális környezetbe, ennek hatékonysága azonban elmaradt az osztálytermi tanítás hatékonyságától. A pedagógusok és a szülők megítélése szerint is lassabban haladtak a gyermekek az olvasástanulással. A tanulók többségének az olvasási motivációja csökkent az osztálytermi helyzethez viszonyítva. Az iskola kezdő szakaszában a hatékony távolléti tanulás elengedhetetlen feltétele a pedagógusok és a szülők szoros együttműködése. A korai olvasástanítás eredményességének növeléséhez új tanítási módszerek kidolgozására és gyakorlati elterjesztésére van szükség.
\end{abstract}

Kulcsszavak: Covid19, távolléti oktatás, korai olvasástanítás, olvasási készségek, olvasási motiváció

A Covid19-világjárvány 2020 márciusában elérte Magyarországot is, melynek hatására a kormány felfüggesztette a jelenléti oktatást, tantermen kívüli digitális munkarendet írt elő, mely érintette az általános iskola első és második évfolyamát is. A digitális oktatással kapcsolatban az olvasástanítás 
vizsgálata kiemelten fontosnak tekinthető, mert az online környezet, a jelenléti oktatás nélküli időszak, az új kihívások jelentősen megváltoztathatják az olvasástanítás hatékonyságát. Molnár és munkatársainak (2021) vizsgálata szerint a koronavírus-járvány hatására a 2020/2021-es tanévben az olvasásszövegértés, a matematika valamint a természettudományok területén a tanulói teljesítmények alacsonyabbak voltak, mint az előző két tanévben.

A pedagógusoknak, a szülőknek és a tanulóknak egyaránt számos nehézséggel kellett szembenézniük a digitális oktatás során. A digitális munkarend minden bizonnyal az iskola kezdő szakaszában tanuló gyermekeket érintette a legsúlyosabban, hiszen az első és második osztályos gyermekek még nem tudnak önállóan tanulni. Az online oktatás során az otthoni tanulásra szánt idő mennyisége megemelkedett, ezzel párhuzamosan még inkább felértékelődött a szülők szerepe a tanulás segítésében (Engler etal., 2021; Józsa et al., 2021; Porubčanová et al., 2021). Emellett a pedagógusok munkaóráinak száma is megnőtt a digitális oktatás idején (N. Kollár, 2021). A távolléti oktatást nehezítették a technikai felszereltségben, valamint a pedagógusok és tanulók informatikai felkészültségében meglévő hiányosságok (Jakab, 2020).

Jelen tanulmányunk fókuszában a Covid19-helyzet miatt kialakult otthoni digitális oktatás vizsgálata áll. Kiemelten összpontosítunk az iskola kezdő szakaszában folyó olvasástanítás és -tanulás eredményességére a szülők és a pedagógusok tapasztalatai alapján.

\section{Olvasástanítás}

Az olvasás tanítása, a tanulók olvasni tudása hosszú ideje a hazai oktatás egyik legneuralgikusabb pontjának számít. A nemzetközi PISA-vizsgálatok (Program for International Student Assessment) eredményei alapján a magyar diákok körülbelül 20\%-ának súlyos olvasási problémái vannak (OECD, 2016; Ostorics et al., 2016). Ez azt jeleneti, hogy minden ötödik tanulónak komoly szövegértési nehézségei vannak. Ezek a tanulók nem értik meg, amit olvasnak. Nem tudják az olvasástudásukat eszközként használni a többi tantárgy tanulásához, nem képesek a hétköznapi életben szükséges szövegek értő feldolgozására. Az olvasástanításnak joggal van kiemelkedő hangsúlya az iskolában, hiszen az olvasási képesség, a szövegértés az oktatás hatékonysága szempontjából az egyik legfontosabb tudáselem. A tanulók olvasni tudása közvetlen hatással van az iskolai tanulás eredményességére (D. Molnár et al., 2012; Józsa \& Steklács, 2009, 2012).

Az olvasási képesség definíciói (áttekintésül lásd például D. Molnár et al., 2012; Józsa \& Steklács, 2009) közül külön kiemelendő Nagy József (2004) modellje. E modell rendszerbe szervezi az olvasási képesség összetevőit: rutinokból, készségekből és ismeretekből építi fel az olvasási képesség komplex rendszerét. Olvasási készségeknek nevezi az olvasástechnikai összetevőket: beszédhanghallás, betűolvasás, szóolvasás, mondatolvasás. Az olvasási készségek fejlettsége kritikus előfeltétele a szövegértésnek. Emellett a hatékony 
szövegértésnek további fontos feltételét képezik az olvasási stratégiák és az olvasási motiváció (Józsa \& Józsa, 2014).

A pedagógiai gyakorlat szempontjából különösen hasznos Nagy József fenti modellje, mivel kiindulópontot ad a különböző olvasástanítási módszerek, értékelési szempontok kidolgozásához, felépítéséhez (Csapó \& Csépe, 2012; Csapó et al., 2015; Józsa, 2006). Ha az olvasás bármelyik összetevőjének fejlődése megkésik, megreked, akkor az gátat jelent a többi összetevő fejlődéséhez is, így kihat a teljes olvasásképességre, szövegértésre (Józsa \& Steklács, 2009; Nagy, 2004).

Az olvasási készségek elsajátításában az általános iskola első és második osztályának döntő szerepe van. Ekkor zajlik a szövegértés kritikus előfeltételeinek, az olvasási készségeknek a fejlesztése: a fonématudatosság, a betű-hang integráció fejlesztése, megszilárdítása. Ennek az időszaknak a feladata a betüfelismerő rutin és a szófelismerő rutin kialakítása. A betűfelismerő rutin a betűk automatikus felismerését teszi lehetővé. A szófelismerés a vizuális jelek alapján aktiválja a szó jelentését. A szófelismerés, szóolvasás két szinten valósulhat meg: betüző szóolvasó és rutinszerű szóolvasó készségként. A betűző szóolvasó készség a szavakban lévő betük szeriális felismerését és egybekapcsolását jelenti, amely nagyon idö- és figyelemigényes folyamat. A folyékony olvasás alapja a hatékony és automatikus szófelismerés. A folyékonyságnak három eleme érdemel külön említést. Gyors és pontos szófelismerés, ennek fó pillére a fonéma-graféma megfeleltetési szabályok automatizálódása, aminek egyik alapja a gyakori olvasás. A második tényező a hangos olvasás esetén a prozódiai tényezők ismerete, amely az olvasás közben kell, hogy megjelenjen. Ez azt jelenti, hogy el kell jutnia a gyermeknek arra szintre, hogy a jelentésre koncentrálva, értelmezve tudja felolvasni a szöveget. A harmadik fontos eleme a folyékony olvasásnak maga a megértés, amely nélkülözhetetlen tényező a szöveg olvasásában, átélésében. Csak akkor fordítható több kapacitás a jelentés alkotására (a megértésre), ha a figyelmet nem köti le a szófelismerés, a dekódolás folyamata (Józsa \& Steklács, 2009).

\section{Digitális munkarend}

Az olvasási készségek digitális munkarendben történő tanításának nincs még kialakult hazai módszertana. A pedagógusok többsége a vírus időszakát megelőzően soha nem tanult, nem tanított online környezetben. Az online oktatás hatékony, sikeres működéséhez más kompetenciákra, készségekre van szükség, mint a hagyományos, jelenléti oktatásban (Jakab, 2020). A tantermi oktatáshoz képest az elektronikus eszközökkel támogatott oktatás esetében a pedagógusnak is megváltozik a szerepe, melyben nélkülözhetetlen a magas színvonalú szakmai tudás, a digitális eszközök aktív, kreatív használata. A hagyományos tantermi oktatásban legtöbbször a tanító, a tanár az oktatás főszereplője, ezáltal a tanulók gyakran passzív helyzetben vannak. Azonban az online környezetben más attitủddel kell, hogy rendelkezzen a pedagógus, hogy felkeltse és fenntartsa tanítványainak motivációját, figyelmét (Bánkeszi \& Szepesi, 2018). 
A tananyagot a tanulóknak nem intézményi környezetben, hanem otthon kellett elsajátítaniuk. Ennek következtében a szülőknek is kihívást jelentett ez az időszak. A fiatalabb korosztályokban a szülői szerep még inkább felértékelődött. A pedagógusoknak a tanítás hatékonysága miatt több feladatba is be kellett vonniuk a szülőket, ilyen például a tanulás támogatása, a motiválás, az értékelés, ellenőrzés, a feladattartás és a fegyelem, az informatikai eszközök kezelése (Farkas et al., 2021).

A különböző korú tanulókkal foglalkozó pedagógusokat összehasonlító vizsgálatok azt mutatják, hogy a pandémiás időszak során az alsó tagozatos tanítók érezték magukat a leghatékonyabbnak. Esetükben feltehetően a szülők segítségnyújtása, támogatása növelte az eredményességet. Ez azt jelenti, hogy alsó tagozaton a szülők nagymértékben segítik gyermekeiket, míg a felső tagozaton, valamint a középiskolában a szülői segítségadás, a szülői kontroll gyakran részben vagy teljesen hiányzik, mely kihat a pedagógusok hatékonyságérzésére is (Jagodics et al., 2020; Józsa et al., 2021).

A tanulók eszközellátottságban és internetelérésben meglévő egyéni különbségei hazai (Jakab, 2020; Kende et al., 2021) és nemzetközi (Stelitano et al., 2020) viszonylatban is nagyok. Ezek a különbség világszerte tovább rontották a hátrányos helyzetű tanulók oktatáshoz való hozzáférését (OECD, 2020).

\section{A vizsgálat célkitüzése}

A kutatásunk célja az volt, hogy megismerjük a pedagógusok és a szülők véleményét a digitális munkarendben megvalósuló kezdő olvasástanításról, -tanulásról, valamint annak eredményességéről.

\section{A vizsgálat módszerei}

Empirikus vizsgálatunk fókuszában azok az alsó tagozaton tanító pedagógusok álltak, akik digitális munkarendben tanítottak első és második osztályos gyermekeket olvasásból, továbbá olyan szülők, akik ugyanebben az időszakban az elsős, másodikos gyermeküknek segítették az otthoni tanulását. Az online kérdőívek kitöltésében 117 fő olvasást tanító pedagógus és 83 fő szülő vett részt. Kényelmi mintavételi technikát alkalmaztunk (Gliner et al., 2017), a válaszadás önkéntes és anonim volt. Az adatgyüjtésre a pedagógusok és a szülők esetében is 2021 februárjában került sor. Ez az adatfelvételi időpont azt jelenti, hogy a kérdőívek kitöltésekor a pedagógusoknak az első iskolabezárási időszakról voltak tapasztalataik. A második iskolabezárási periódusra az adatfelvételünket követően, 2021 tavaszán került sor.

A kérdőívet kitöltő tanítók átlagéletkora 49 év volt, nem volt közöttük olyan, akinek ez lett volna az első tanéve. A 2020. tavaszi iskolabezárás idején első osztályban tanított 55\%-uk, második osztályban 45\%-uk. A pedagógusok $98 \%$-a, a szülők $96 \%$-a nő. 


\section{Eredmények és értelmezés}

\section{Olvasástanítás a digitális munkarendben a pedagógusok megítélése szerint}

Az elemzések egyik központi kérdése az volt, hogy mennyire érezték hatékonynak a pedagógusok a digitális oktatás során az olvasástanítást. Azt kértük tőlük, mondjanak arról véleményt, hogy a digitális munkarend adta lehetőségek között milyen mértékben tudták megtanítani a gyermekeket olvasni. Azt kellett megítélniük, hogy az osztálytermi oktatással összehasonlítva milyen eredményességű volt az olvasástanításuk, a tervezett tananyag hány százalékát sajátították el a gyermekek. A hagyományos, osztálytermi olvasástanítás eredményességét tekintettük 100\%-nak, ehhez viszonyítva digitális munkarendben milyen mértékben tanultak meg a diákok olvasni.

A tanítók véleményének százalékos megoszlását az 1. ábra mutatja. Az ábrából egyértelműen kitűnik, hogy nagy különbségek vannak a pedagógusok véleményében, 0 és $100 \%$ között minden érték előfordul. A tanítók mindössze $5 \%$-a véli úgy, hogy teljes mértékben meg tudta tanítani az olvasás tananyagot, 17\%uk gondolja 90\% felettinek a megtanított tananyagot. A pedagógusok harmada ugyanakkor úgy érzi, hogy a tananyag kevesebb, mint felét tudta csak megtanítani digitális körülmények között. A válaszok átlagát kiszámolva 66\%-ot kapunk. Ez azt jelenti, hogy a tanítók - saját megítélésük szerint - átlagosan a tananyag mintegy kétharmad részét tudták megtanítani. Az első és második évfolyamon tanító pedagógusok véleménye között nincs szignifikáns különbség ( $\mathrm{F}=0,32$, $\mathrm{p}=0,57, \mathrm{t}=0,50, \mathrm{p}=0,62)$. Ugyancsak nincs különbség a fiatalabb és a gyakorlottabb pedagógusok megítélése között $(\mathrm{F}=1,76, \mathrm{p}=0,19, \mathrm{t}=0,01, \mathrm{p}=0,99)$.

\section{1. ábra}

A pedagógusok megitélése arról, hogy az olvasás tananyagot milyen mértékben sikerült megtanitani digitális munkarendben

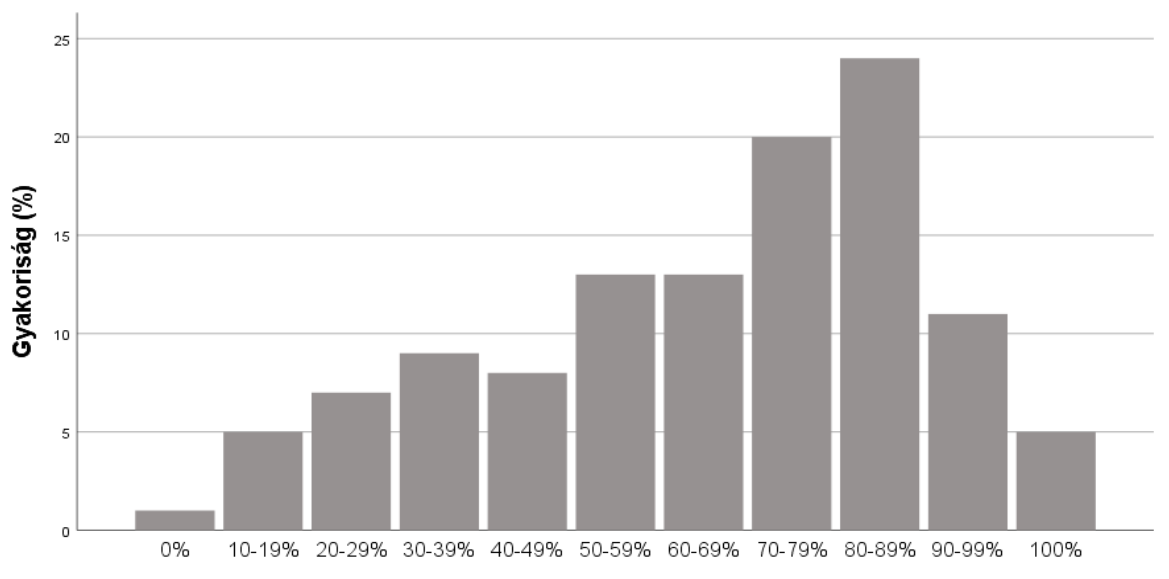

Az olvasás tananyag megtanítása 
Az 1. táblázat tartalmazza a pedagógusok véleményének a megoszlását aszerint, hogy az általuk tanított osztályban meddig jutottak el az olvasástanításban év végére a digitális munkarend idején. Emellett véleményt formáltak arról is, hogy ugyanezzel az osztállyal meddig jutottak volna el hagyományos, osztálytermi keretek között a tananyag elsajátításában. A táblázat adatai ennek köszönhetően összehasonlítást tesznek lehetővé aközött, hogy az olvasási készségek megtanításának az ütemében, eredményességében milyen különbséget látnak a tanítók a digitális és az osztálytermi tanítás között.

Az első osztályban tanító pedagógusok úgy vélik, hogy tanév végére a betük megtanítása osztálytermi körülmények között minden esetben megtörtént volna. Digitális körülmények között a pedagógusok 91\% jutott el az összes betű megtanításáig. Ehhez hasonló, kismértékű különbség mutatkozik a szóolvasó készség elsajátításában is. Jóval nagyobb eltérést éreznek a pedagógusok a mondatértés, valamint a szövegértés megtanítása esetében. Első osztály végére osztálytermi körülmények között a pedagógusok 73\%-a jutott volna el a mondatok megértésének tanításáig, digitális munkarendben ez az arány csak 46\%. A szövegértés tanításáig hagyományos keretek között a pedagógusok 70\%-a jutott volna el, ez az arány digitális munkarendben csak 24\%. Ehhez hasonló karakteres különbségek mutatkoznak második osztályban is a pedagógusok szerint. (1. táblázat) Az adatok alapján egyértelműen megállapítható, hogy a tanítók jelentős különbséget éreznek a két tanítási munkarend között abban, hogy milyen mértékben tudtak előre haladni az olvasás tanításával.

\section{1. táblázat}

Az olvasás komponenseinek megtanitásában való elörehaladás a tanév végére a pedagógus megítélése szerint (\%)

\begin{tabular}{|l|c|c|c|c|}
\hline \multirow{2}{*}{ Olvasás komponensei } & \multicolumn{2}{|c|}{ Első évfolyam } & \multicolumn{2}{c|}{ Második évfolyam } \\
\cline { 2 - 5 } & Tantermi & Digitális & Tantermi & Digitális \\
\hline betúk & 100 & 91 & 100 & 98 \\
\hline betúkapcsolatok & 92 & 88 & 98 & 92 \\
\hline szavak & 92 & 85 & 96 & 84 \\
\hline szókapcsolatok & 89 & 73 & 96 & 82 \\
\hline mondatértés & 73 & 46 & 82 & 64 \\
\hline szövegértés & 70 & 24 & 75 & 32 \\
\hline
\end{tabular}

A pedagógusok szerint a tanulók olvasás iránti érdeklődése, motiváltsága számottevően csökkent az osztálytermi tanításhoz viszonyítva. (2. táblázat) Az olvasás tanulása iránti érdeklődést az osztálytermi helyzettel hasonlítottuk össze. A tanítók 61\%-a úgy látja, hogy a gyermekek kevésbé motiváltak az olvasás tanulására a digitális munkarend során. A pedagógusok harmada szerint a motiváltságban nem következett be lényegi változás. Az olvasás iránti motiváltság növekedését mindössze a tanítók 5\%-a érzékelte. 
Az olvasási motiváció csökkenésének komoly kihatása lehet az olvasási képesség fejlődésére. Az olvasási motiváció csökkenésének a következtében a gyermekek kevesebbet foglalkoznak az olvasással, kevésbé fókuszált a figyelmük, aminek a következtében az olvasási képességük is lassabban fejlődik (lásd Józsa \& Józsa, 2014; Szenczi, 2013).

\section{2. táblázat}

A tanulók olvasás iránti motivációja a digitális munkarend idején az osztálytermi oktatás során tapasztaltakhoz viszonyítva

\begin{tabular}{|l|c|}
\hline \multicolumn{1}{|c|}{ Olvasási motiváltság } & \% \\
\hline sokkal kevésbé & 17 \\
\hline kevésbé & 44 \\
\hline ugyanannyira & 34 \\
\hline jobban & 4 \\
\hline sokkal jobban & 1 \\
\hline
\end{tabular}

A pedagógusok számára komoly kihívást jelentett a hagyományos olvasástanítási módszerek online környezetbe történő integrálása. A legtöbb pedagógus (71\%) nem tartja hatékonynak a tradicionális olvasástanítási módszereket online környezetben. A tanítók 23\%-a ugyanakkor a tantermi oktatáshoz képest nem változtatott lényegileg a módszerein. Mindössze a tanítók 3\%-a nyilatkozott úgy, hogy teljes mértékben módosította a megszokott olvasástanítási módszereit. Jellemző volt, hogy a digitális munkarendben az olvasástanítás több eleme kimaradt, amelyet a tanítók nem tudtak megvalósítani, valamint hiányoltak a tantermen kívüli, digitális oktatás olvasástanítási lehetőségeihez képest. Az online környezetben történő segítségnyújtás, támogatás esetében a pedagógusok módszerei közül jellemzőek voltak a digitális interaktív játékok (86\%), valamint a tankönyvi, munkafüzeti feladatok feldolgozása és megoldása (83\%). A tantermen kívüli tanulási folyamat támogatása során a pedagógusok elsősorban YouTube-videókat (60\%), videóhívásokat (58\%) említettek. Véleményük összefoglalóan azt tükrözi, hogy a megváltozott oktatási környezet a legtöbb esetben az olvasástanítás módszertani repertoárjának beszükülését vonta maga után, ami valószínűsíti az olvasástanítás csökkenő hatékonyságát.

A tanítók egyharmada tartja az online környezetben megvalósuló olvasástanítást a tantermi oktatással azonos hatékonyságúnak. Egyetlen pedagógus sem gondolta azonban úgy, hogy sokkal hatékonyabb lenne az ismeret- és a tananyagátadás a tantermen kívüli digitális munkarendben. Nincs különbség az első és a második osztályban tanító pedagógusok között abból a szempontból, hogy mennyire érezték hatékonynak a digitális olvasástanítást $(\mathrm{F}=1,08, \mathrm{p}=0,30, \mathrm{t}=1,24, \mathrm{p}=0,22)$.

A tanítók válaszai egyértelműen kiemelték, hogy a szülöi segítség elengedhetetlen ahhoz, hogy a digitális olvasástanítás hatékony legyen. Ezt a 
segítséget azonban sok család esetében nem kapták meg a gyermekek. Sok esetben a szülők nem tudtak, vagy nem megfelelő mértékben tudtak segíteni gyermekeiknek. A szülői támogatás részben (34\%) vagy teljes mértékben hiányzott (24\%). A hátráltató tényezők között többször fordult elő a digitális eszközök vagy az internetkapcsolat hiánya (12\%). Természetes, hogy a legtöbb gyermek ebben az életkorban még nem tud önállóan feladatot értelmezni és megoldani. A pedagógusok szerint azonban a szülők egy része (8\%) számára is komoly nehézséget jelentett a feladatok megoldása, ezért nem tudtak segíteni a gyermeküknek. A válaszok alapján erősen valószínűsíthető, hogy a családi háttér következtében meglévő különbségek a digitális munkarend alatt még inkább felerősödtek.

A pedagógusok válaszai az egyéni bánásmódot igénylő tanulók digitális oktatásában rejlő kihívásokra is felhívták a figyelmet. Ezt illusztrálja az alábbi két idézet. „Halmozottan hátrányos helyzetü tanulókkal dolgozom, igy nem volt lehetöség a digitális oktatásra, csak a papír alapú távoktatásra. A családi háttér pedig a legtöbb gyermeknél nem tette lehetövé új tananyag elsajátítását.” Egy másik idézet: „Integrált tanulókat tanítok. Sokkal lassabban haladtunk a tananyaggal, mert az iskolában többet tudtunk gyakorolni, hatékonyabb volt az oktatás, otthon a szülöt nem terhelhettem annyira, hogy annyit gyakoroljanak és olyan módon, ahogy velem szoktak."

A pedagógusok ugyanakkor a digitális oktatás néhány pozitívumát is megemlítették. Páran rámutattak az online, játékos, interaktív feladatok előnyeire, néhányan kiemelték a gyermekek önállóságra nevelését. A megkérdezettek 4\%-ának könnyebbséget jelentett az online módon való differenciálás. Néhány tanító a digitális munkarend pozitívumának tartotta a szülőkkel való hatékonyabb együttműködés megvalósulását.

\section{Digitális olvasástanitás a szülök megítélése szerint}

A szülők 70\%-a számára komolyabb nehézségeket jelentett a digitális munkarendre történő átállás. Mintegy negyedük érezte úgy, hogy az átállás csak kis mértékủ terhet és nehézséget jelentett. A két válaszkategóriát együtt tekintve azt mondhatjuk, hogy a szülők 95\%-a számára jelentett a digitális munkarend többlet nehézségeket. Mindössze a szülők 5\%-a gondolja, hogy ugyanolyan megterhelést jelentett számára a gyermeke otthoni tanulása, mint a hagyományos oktatás. Nem volt olyan, akinek a digitális munkarend könnyebbséget jelentett volna a hagyományos munkarendhez képest. Az első és a második évfolyamos gyermekek szülei között nem volt különbség a digitális átállással járó nehézségek megítélése szempontjából $(\mathrm{F}=0,008$, $\mathrm{p}=0,93 ; \mathrm{t}=1,27, \mathrm{p}=0,21$ ).

Összehasonlítottuk az olvasástanuláshoz nyújtott otthoni segítség időtartamát a digitális munkarendben és a hagyományos oktatás esetében. A 3. táblázat adataiból látható, hogy a szülőknek jelentősen megnőtt az időterhelése. A legalább két órát segítő szülők aránya a hagyományos oktatásban $6 \%$ 
volt, a digitális oktatásban ez 29\%-ra nőtt. A segítségnyújtás négyfokú skálán mért időtartamának átlaga a hagyományos oktatásban 1,37-ről a digitális oktatásban 2,06-ra nőtt meg, ami szignifikáns növekedés $(\mathrm{t}=6,11 ; \mathrm{p}<0,001)$. A korrelációs együttható alapján gyenge-közepes összefüggés van a digitális munkarend és a hagyományos oktatás során nyújtott segítség időtartama között $(\mathrm{r}=0,32, \mathrm{p}<0,05)$. Ez azt mutatja, hogy kapcsolat van a hagyományos és a digitális oktatásban nyújtott szülői segítség között: azok a szülők nyújtanak több segítséget a digitális munkarendben, akik az osztálytermi tanulás során is segítenek a gyermeknek.

\section{3. táblázat}

A szülők segítségnyújtásának idötartama olvasásból egy nap

\begin{tabular}{|l|c|c|}
\hline \multirow{2}{*}{$\begin{array}{c}\text { Segítségnyújtás olvasásból } \\
\text { egy nap }\end{array}$} & \multicolumn{2}{|c|}{ Arány (\%) } \\
\cline { 2 - 3 } & Digitális munkarendben & Hagyományos oktatásban \\
\hline egy óránál kevesebbet & 36 & 70 \\
\hline egy órát & 35 & 24 \\
\hline két órát & 16 & 5 \\
\hline két óránál többet & 13 & 1 \\
\hline
\end{tabular}

A ráfordított idő növekedésének ellenére a szülők több mint fele (54\%) úgy érzi, hogy nem tudott a gyermekének elegendő mértékben segíteni. Egyetlen szülő sem érezte úgy, hogy teljes mértékben tudta volna kompenzálni az osztálytermi oktatás hiányát az otthoni tanulással. Ebből a szempontból sem volt szignifikáns különbség az első és a második évfolyamos szülők között. A szülők a digitális olvasástanításnak több hátrányát is megemlítették. Sokan kiemelték, hogy olyan feladatok hárultak rájuk az olvasástanítással kapcsolatban, amihez szülőként nincs meg a megfelelő szakértelmük, nem értenek az olvasástanításhoz, annak módszertanát nem ismerik. Sokan egyértelmüen rámutattak, hogy két különböző szerep a tanítói és a szülői, s a digitális munkarend tanítói szerepet vár el tőlük.

Ezek mellett a szülők negyede említette, hogy a gyermeke nem akart együttmüködni a digitális munkarend során, nehezen lehetett odaültetni a számítógéphez, nehezen lehetett rávenni a tanulásra, nem tudták kellő mértékben motiválni az olvasásra. A szülők 20\%-a emelte ki, hogy nem jutott elég idő a tanulásra a munkahely, a testvérek, a családi teendők miatt.

Volt szülő, aki megemlítette, úgy érzi, hogy bár szakmailag tudta kompenzálni a jelenléti oktatás hiányát, de hiányoztak a barátok, a csoporttevékenységek, a személyes tanulás előnyei. Emiatt a körülményeket tekintve nem tudta azt adni, amit a jelenléti oktatás tudott volna.

A szülők véleményt formáltak arról, hogy milyennek érzik gyermekük olvasástanulási motivációját, érdeklődését a digitális oktatás során. Úgy tettük fel a kérdést, hogy az osztálytermi oktatáshoz viszonyítsanak, ehhez képest 
ítéljék meg a gyermekük motivációját. A szülők szerint a tanulók több mint fele (55\%) kevésbé motivált az olvasás megtanulására, mint az osztálytermi oktatás során volt. A gyermekek 32\%-ánál nem tapasztaltak különbséget, változást a szülők az olvasástanulási motivációban. Emellett 13\%-nyi azon gyermekeknek az aránya, akik a szülők szerint nagyobb érdeklődést mutattak a digitális munkarendben, mint korábban.

A pedagógusok mintegy felénél érezték úgy a szülők, hogy ugyanolyan a pedagógus tanítás iránti lelkesedése, mint osztálytermi környezetben. A pedagógusok 13\%-nál a tanítás iránti lelkesedés csökkenését, míg 37\%-nál a lelkesedés növekedését érezték a szülők. Nehéz megmondani, hogy valóban változott-e a pedagógusok tanítás iránti motiváltsága, vagy csak a szülők látták őket más szerepben, más helyzetben. Bármelyik is a valós ok, fontos, hogy a szülők mit érzékelnek a pedagógus munkájával kapcsolatban. Pozitívumnak tekinthető, hogy több szülő számolt be a pedagógusok tanítás iránti motivációjának a növekedéséről, mint annak csökkenéséről.

\section{Összegzés}

Empirikus vizsgálatunkban azzal foglalkoztunk, hogy a digitális munkarend idején milyen eredményességgel valósult meg a kezdő olvasástanítás. Első és második osztályban tanító pedagógusokat, valamint szülőket kértünk arra, hogy hasonlítsák össze az osztálytermi és a digitális olvasástanítást. Eredményeink szerint sem a pedagógusok, sem a szülők nem találták olyan hatékonynak a digitális munkarendet, mint a hagyományos, osztálytermi oktatást. A tanítók többsége úgy látja, hogy kevésbé tudta megtanítani a tanulókat olvasni ebben a formában, lényegesen lassabban haladtak az olvasástanítással, -tanulással. Úgy ítélik, hogy az osztálytermi oktatáshoz viszonyítva csak körülbelül a tananyag kétharmadát sikerült elsajátítaniuk a tanulóknak. Mindemellett a pedagógusok a terhek, feladatok növekedését érzékelték az online tanítás során, ami érthető, hiszen alapvetően új kihívások, új feladatok elé állította ez a helyzet őket. A legtöbb tanító a hagyományos olvasástanítási módszereket próbálta használni, adaptálni a digitális környezetbe. Ezek a módszerek azonban a digitális környezetben csak részben hatékonyak. Az online oktatás során alkalmazható új módszerek kidolgozása és elterjedése egyelőre még csak gyerekcipőben jár.

A pedagógusok szerint első és második évfolyamon hasonló nehézségeket okoz a digitális munkarendben folytatott olvasástanítás. Egyforma eredményességgel tanítható mindkét évfolyam, s mindkét korosztály kevésbé hatékonyan, mint osztálytermi környezetben. E tekintetben nincs különbség a kezdő és a gyakorlott pedagógusok megítélése között.

A gyermekek 10-15\%-a számára a digitális munkarend nem volt elérhető. Nem állt rendelkezésre számukra a megfelelő internetelérés, hiányoztak az informatikai eszközök, nem volt meg az otthoni tanulást biztosító nyugodt környezet. A tanítók a digitális oktatás mellett, illetve részben helyett más 
módszerekkel, például papíralapú levelezéssel igyekeztek őket segíteni. Valószínűsíthető, hogy a gyermekek egy csoportjának a tanulásban való lemaradása a digitális munkarend időszaka alatt tovább növekedett.

A pedagógusok és a szülők egybehangzó véleménye szerint a gyermekek nagy részének jelentősen csökkent az olvasási kedve a digitális munkarend idején. Ugyanakkor mind a pedagógusok, mind a szülők úgy látják, hogy voltak olyan gyermekek is, akiknél nőtt az olvasási motiváció. További kutatások válaszolhatnak arra, hogy mi eredményezhette a tanulók egy részénél az olvasási motiváció növekedését, az olvasási motiváció változása miként befolyásolható digitális munkarendben.

A szülőkkel való szoros együttműködés az olvasástanítás eredményessége szempontjából ebben az életkorban elengedhetetlen. A szülők nagy hányadának azonban nincs elegendő ideje és szakmai tudása ahhoz, hogy megfelelő mértékben segítse a gyermek olvasástanulását. A hagyományos oktatáshoz viszonyítva számottevően megnőtt az az időtartam, amelyben az olvasástanítást segítik a szülők. Azok a szülők segítenek többet a gyermekeiknek, akik az osztálytermi oktatás során is segítették őket az olvasástanulásban. Az első és a második évfolyamokon tanuló gyermekek szüleinek véleménye szerint nincs lényegi különbség az otthoni tanulás nehézségét illetően. Sok szülő beszámolt arról, hogy nehéz volt a gyermeket a tanulásra rávenni, nehéz volt a számítógéphez odaültetni.

A vizsgálatunkból levonható következtetések általánosíthatóságában korlátot jelent, hogy az adatfelvétel önkéntes, online formában valósult meg. Nem tudjuk, hogy mennyiben térnek el a digitális oktatással kapcsolatos tapasztalatai azoknak, akik nem tudtak vagy nem akartak bekapcsolódni az önkéntes, anonim adatfelvételbe. A digitális eszközöket és az internetet korlátozottan elérő szülők nagy valószínűséggel kimaradtak a vizsgálatunkból. Jóllehet, ezeknek a családoknak a gyermekei kiemelt figyelmet kell, hogy kapjanak a távolléti oktatás idején.

Összességében elmondható, hogy a hagyományos oktatást ma még nem lehet teljes mértékben helyettesíteni a tantermen kívüli digitális munkarenddel, főleg nem ebben a korosztályban. Az iskola kezdő szakaszában rendkívül fontos a pedagógus személye, szakmai tudása a hatékony tanítás, tanulás szempontjából. A digitális munkarendben megvalósuló olvasástanítás eredményességének a növeléséhez elengedhetetlen az új olvasástanítási módszerek kidolgozása, hatékonyságvizsgálata, és az új módszerek széles körủ megismertetése a gyakorló pedagógusokkal és a szülőkkel.

\section{Köszönetnyilvánítás}

A kutatást az EFOP-3.1.2-16-2016-00001 számú projekt támogatta. 


\section{Irodalom}

Bánkeszi, K. \& Szepesi, J. (2018). Módszertan és eszköztár elektronikus oktatási környezetben. Könyvtári Figyelö, 64(3), 377-390. http://epa.oszk. hu/00100/00143/00353/pdf/EPA00143_konyvtari_figyelo_2018_3_377-390.pdf

Csapó, B. \& Csépe, V. (2012, Eds.). Tartalmi keretek az olvasás diagnosztikus értékeléséhez. Nemzeti Tankönyvkiadó.

Csapó, B., Steklács, J. \& Molnár, Gy. (2015, Eds.). Az olvasás-szövegértés online diagnosztikus értékelésének tartalmi keretei. Oktatáskutató és Fejlesztő Intézet.

D. Molnár, É., Molnár, E. K. \& Józsa, K. (2012). Az olvasásvizsgálatok eredményei. In Csapó, B. (Ed.), Mérlegen a magyar iskola (pp. 17-81). Nemzeti Tankönyvkiadó. https://mek.oszk.hu/12300/12314/12314.pdf

Engler, Á., Markos, V. \& Dusa, Á. R. (2021). Szülői segítségnyújtás a jelenléti és távolléti oktatás idején. Educatio, 30(1), 72-87. https://doi.org/10.1556/2063.30.2021.1.6

Farkas, A., Földeáki, A., Főző, A. L., Frész, A J., Genáhl, K. J., Horváth, Á., Jánossy, Zs., Kapcsáné, N. J., Krajcsovicz, Á., Neumann, V., Pintér, G., Sió, L., Szabados, T., Szalay, S. Zs., Szilágyi, Á., Timár B. \& Tóth T. (2021). Digitális pedagógiai módszertani ajánlások gyüjteménye. Oktatási Hivatal. https://www.oktatas. hu/pub_bin/dload/kozoktatas/tavoktatas/Modszertani_gyujtemeny_01_08_ honlapra.pdf?fbclid=IwAR30VxV9Q2ccD6drMsUb8EXUxHuVWxGmwGUiI3 nA_mR01O3EIxMVhB0I-vU

Gliner, J. G., Morgan, G. A. \& Leech, N. L. (2017). Research methods in applied settings: An integrated approach to design and analysis. Routledge/Taylor \& Francis Group. https://doi.org/10.4324/9781315723082

Jagodics, B., Kóródi, K. \& Szabó, É. (2020). Az észlelt tanári énhatékonyságot befolyásoló tényezők vizsgálata a kényszerü digitális oktatás időszakában (2. rész). Iskolakultúra, 30(11), 24-43. https://doi.org/10.14232/ISKKULT.2020.11.24

Jakab, G. (2020). ISKOLA - járvány idején (1. rész). Iskolakultúra, 30(9), 64-76. https://doi.org/10.14232/ISKKULT.2020.9.64

Józsa, G. \& Józsa, K. (2014). A szövegértés, az olvasási motiváció és a stratégiahasználat összefüggése. Magyar Pedagógia, 114(2), 67-89.

Józsa, G., Karáné Miklós, N. \& Józsa, K. (2021). A tanulók motiválása a tantermen kívüli, digitális munkarend idején - a pedagógusok tapasztalatai. Gyermeknevelés Tudományos Folyóirat, 9(2), 169-186.

Józsa, K. (2006, Ed.). Az olvasási képesség fejlődése és fejlesztése. Dinasztia Tankönyvkiadó.

Józsa, K. \& Steklács, J. (2009). Az olvasástanítás kutatásának aktuális kérdései. Magyar Pedagógia, 109(4), 365-397.

Józsa, K. \& Steklács, J. (2012). Az olvasás tanításának tartalmi és tantervi szempontjai. In Csapó, B. \& Csépe, V. (Eds.), Tartalmi keretek az olvasás diagnosztikus értékeléséhez (pp. 137-188). Nemzeti Tankönyvkiadó. 
Kende, Á., Messing, V. \& Fejes, J. B. (2021). Hátrányos helyzetű tanulók digitális oktatása a koronavírus okozta iskolabezárás idején. Iskolakultúra, 31(2), 76-97. https://doi.org/10.14232/ISKKULT.2021.02.76

Molnár, G., Hódi, Á., Ökördi, R. \& Mokri, D. (2021). A koronavírus-járvány okozta rendkívüli oktatási helyzet hatása 2-8. évfolyamos diákok tudás- és képességszintjére az olvasásszövegértés, a matematika és a természettudományok területén. Iskolakultúra, 31(2), 3-22. https://doi.org/10.14232/ISKKULT.2021.02.3

N. Kollár, K. (2021). Az online oktatás tapasztalatai és gyakorlata a pedagógusok nézőpontjából. Iskolakultúra, 31(2), 23-53. https://doi.org/10.14232/ ISKKULT.2021.02.23

Nagy, J. (2004). Olvasástanítás: a megoldás stratégiai kérdései. Iskolakultúra, 14(3), 3-26. http://epa.oszk.hu/00000/00011/00080/pdf/iskolakultura_EPA00011_2004_03_003026.pdf

OECD (2016). PISA 2015. Results in focus. OECD Publishing.

OECD (2020). Learning remotely when schools close: How well are students and schools prepared? Insights from PISA. OECD.org

Ostorics, L., Szalay, B., Szepesi, I. \& Vadász, Cs. (2016). PISA 2015 összefoglaló jelentés. Oktatási Hivatal.

Porubčanová, D., Geršicová, Z., Bočková, K., Pasternáková, l., Barnová, S., Rochovská, I., Dolinská, E., Dudek, M. \& Szőköl, I. (2021). Educational challenges in subject didactics education in the context of home education. STS Science Centre, Ltd. in coedition with KEY Publishing.

Stelitano, L., Doan S., Woo, A., Diliberti, M., Kaufman, J. H. \& Henry, D. (2020). The digital divide and Covid-19: Teachers' perceptions of inequities in students' Internet access and participation in remote learning. RAND Corporation, https:// doi.org/10.7249/RRA134-3 https://doi.org/10.7249/RRA134-3

Szenczi, B. (2013). Olvasási motiváció 4., 6. és 8. osztályos tanulók körében. Magyar Pedagógia, 113(4), 197-220. 


\section{Józsa, K. \& Pasztendorf, G.}

\section{Early reading education during Covid19: Perceptions of teachers and parents}

As a consequence of the Covid-19 pandemic, schools in Hungary were closed from March, 2020. The Hungarian government decided to implement digital education: children learning at home were assisted by teachers in the form of remote teaching. We have little information as yet about the effectiveness of digital education during this period. We do not know how the knowledge acquired by students during remote teaching compares to that acquired during face-to-face education. This research therefore aimed to explore the effectiveness of the early teaching and learning of reading. We asked grade 1 and grade 2 elementary school teachers as well as parents about their perceptions of reading education during the period of remote teaching. A voluntary, anonymous online questionnaire was completed by 117 teachers and 83 parents. The findings show that most of the teachers tried to adapt traditional methods of teaching reading to the digital environment during the pandemic, which turned out to be less effective than face-to-face teaching. Both teachers and parents thought that children progressed more slowly with the process of learning to read. For the majority of the students reading motivation was decreased compared to face-to-face learning. The close cooperation of teachers and parents seems essential for effective remote learning in the early years of school. New teaching methods need to be developed and disseminated to increase the effectiveness of early reading education.

Keywords: Covid19, remote teaching, early reading education, reading skills, reading motivation

Józsa Krisztián: https://orcid.org/0000-0001-7174-5067

Pasztendorf Gabriella: https://orcid.org/0000-0002-3193-0046 